\title{
BIOCHAR PRODUCTION FROM WASTE BIOMASS USING MODULAR PYROLYZER FOR SOIL AMENDMENT
}

\author{
K. M. Nazmus Sakib ${ }^{1}$, S. M. Nafiz Ahmed ${ }^{1}$, Abdullahil Mubdee ${ }^{1}$ and Kawnish Kirtania*1 \\ ${ }^{1}$ Department of Chemical Engineering, Bangladesh University of Engineering and Technology, \\ Dhaka - 1000, Bangladesh
}

\begin{abstract}
Nowadays, researchers have found many applications of biochar due to its large surface area, ion and water holding capacity, sheltering possibility for microbes beneficial for the plants' nutrition intake, carbon sequestration etc. Among several waste biomass feedstock, agricultural waste is a suitable source of biomass for the biochar production. So, in this study, a low cost, modular technology was proposed that can be used at the consumer end to produce biochar of satisfactory quality. In this technology, no separate inert gas feed was required, thereby lowering the cost and complexity of the system. The reactor was designed in a way that most of the oxygen got consumed at the beginning of the process and the residual nitrogen from air maintained a pseudoinert environment. As potential feedstock for biochar, rice husk and wood chips were considered in this study. Also, to evaluate the quality of produced biochar, proximate analysis and calorific value were measured. The char yields were found to be between 20 to $40 \%$. For rice husk (powdered and granular) and wood chips, the volatile content (\%) were $15.88,19.69$ and 25.47 respectively meaning most of the volatiles were released during devolatilization. It was found that biochar can be produced from agricultural waste using this method by farmers in the field without any additional equipment, and the pyrolyzer is modular and portable. Finally, the biochar could be used for soil replenishment. Further work is ongoing on the char characterization to realize the full potential of biochar production from waste biomass.
\end{abstract}

Keywords: Biomass, Soil amendment, Biochar, Agricultural waste, Modular pyrolyzer

\section{Introduction}

The utilization of biochar as an amendment to improve soil health and to protect the environment by sequestering carbon has been a catalyst for the recent global enthusiasm for advancing biochar production technology and its management [1-3]. Pyrolysis of biomass produces solid (char), liquid (bio-oil) and gaseous fuel [4]. The yields of the three phase products will vary with operating parameters. Lower process temperature and longer vapor residence time favor char formation. Whereas, higher process temperature and longer vapor residence time favor the formation of liquid products and the moderate state of these two parameters is optimal for gaseous product formation [5]. The solid product here, as it is derived from biomass, is called biochar. Numerous researches have been conducted on the use of biochar for agronomic and environmental benefits [6]. This biochar has been used in various regions of the world to improve soil fertility and sequester carbon (C) via exploitation of its nutrients, its high $\mathrm{C}$ content and the refractory nature of the $\mathrm{C}$ contained [7-9].
The initial interest in biochar is to use it as a mean to capture carbon dioxide from atmosphere and store it in soil in a stable form [8]. In this regard, biochar production has been recognized as a carbon negative technology $[10,11]$. However, recent researches have suggested that biochar's effect on reduction of $\mathrm{N}_{2} \mathrm{O}$ is more noteworthy than its contribution to the reduction of $\mathrm{CO}_{2}$ [12-14].

The production of biochar is tailored by using different feedstocks as precursors and by using different conditions to get physical and chemical properties required to amend damaged soil [15]. In addition, recent studies have shown that biochar can be used as an adsorbent to control and remediate various contaminants in soil and water systems $[1,16]$. Rapid expansion has been made in the application of biochar into areas not previously considered, showing a tremendous potential of biochar application.

One major area of application is agriculture. With the ever-growing population, agriculture aims to meet food demands through balanced fertilization, selection of plant varieties and adequate agricultural engineering. But failure to adopt a well thought out. 
fertilization plan can entail environmental damage [17-19]. Biochar here, is thought to improve soil properties through reduce of acidification, decrease bulk density, enhance retention and cation exchange capacity (CEC) [2,20].

Rice husk and wood chips were used as representative samples of agricultural residue in this study. From well-known pyrolysis techniques, the biochar yield from rice husk precursor is found to be around 30 to $40 \%$ [21]. The proximate analysis of such biochar gives varying results depending on operating conditions. Moisture content is found to be varying from 0.67 to $3.57 \%$, volatile from 7.07 to $76.37 \%$, fixed carbon from 4.37 to $58.12 \%$ and ash from 16.62 to $33.74 \%$ [22]. Similarly, various properties of biochar from wood chips could be found in literature $[23,24]$. Although, there have been many studies of biochar production from pyrolysis tailoring reactor design, pyrolysis conditions, product characterization and quality improvement, only a few of them are cost effective to be adopted by the rural farmers. So, this study aimed at designing a modular pyrolyzer which is cost effective and easy to use at the consumer end. The biochar produced was also characterized thoroughly to evaluate the quality.

\section{Experimental}

\subsection{Biomass feedstock}

Rice husk and wood chips were used as feedstock for producing biochar in this study. Two types of rice husk were used, powdered and granular.

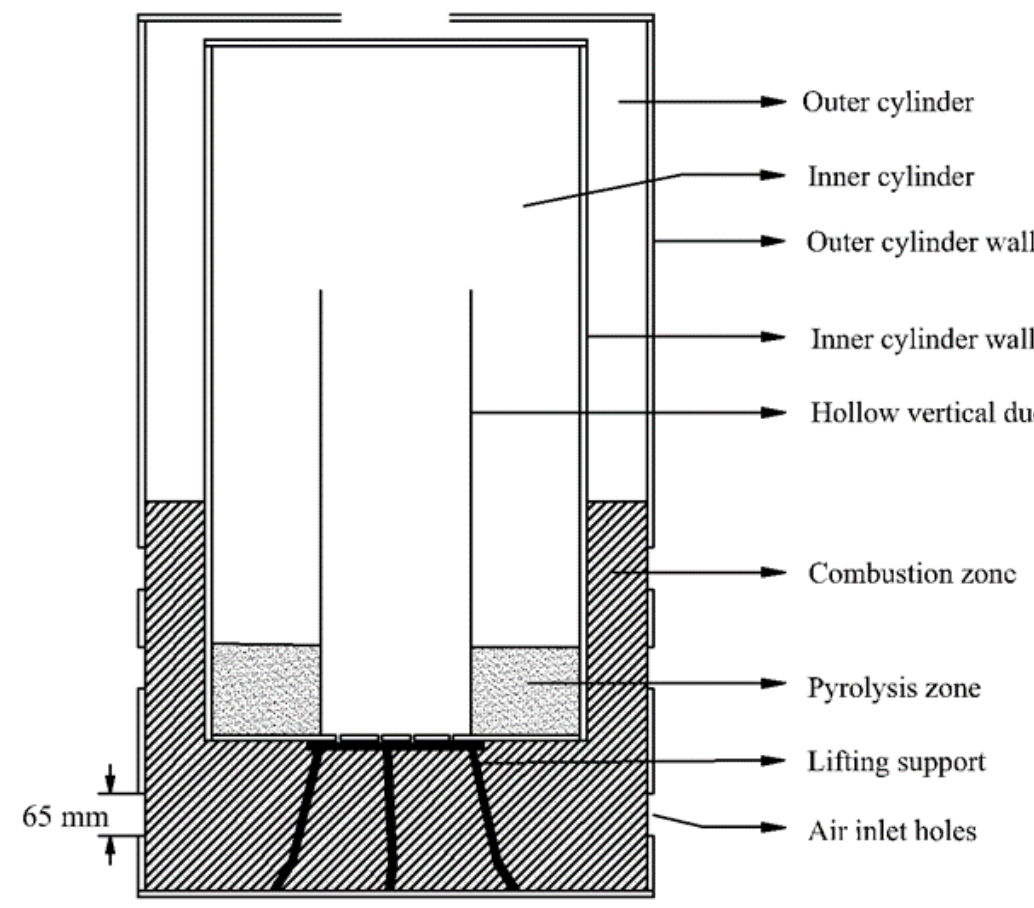

(a)

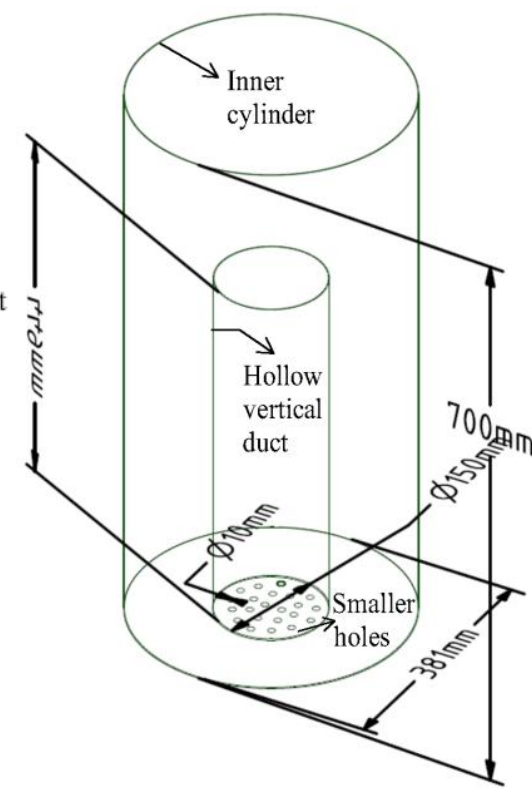

(b)

Fig. 1: (a) Schematic diagram of the modular pyrolyzer, (b) Geometric detail of the inner container of the modular pyrolyzer

\subsection{Modular pyrolyzer}

The modular pyrolyzer consisted of two metallic cylindrical containers which is showed in Fig. 1(a). The outer one had several (10-15) air inlet holes in its surface which were evenly spaced. These holes provided pathways for air to reach the combustion zone. The inner one which contained feedstock, was implanted inside the outer one. It remained closed during the whole process. It was raised to a higher position by a metallic lifting support so that it provides a vicinity for the combustion process to occur to provide heat for the pyrolysis. It also enabled to provide uniform heating around the inner cylinder for the pyrolysis process to occur completely.

The reactor was designed in a way that most of the oxygen get consumed at the beginning of the process which was combustion and the residual nitrogen from air could maintain a pseudo-inert environment. Fig. 1(b) shows the geometric detail of the inner container. There was a hollow vertical duct inside it. The ground surface of the inner container within the 
duct was perforated with several (5-10) smaller holes. These pathways released the volatiles to the combustion zone for burning to provide additional heat for the pyrolysis. The pyrolysis zone remained partitioned from the combustion zone and the duct. Both the containers along with the hollow duct constructed a concentric system.

\subsection{Experimental procedure}

Around 500-1000 g sample of biomass was fed into the inner container of the pyrolyzer for each experimental run. Before starting the combustion process, the space under the inner container and around it was loaded with wood blocks. Around 2.5 $\mathrm{kg}$ of wood blocks were combusted. Around $175 \mathrm{~mL}$ of kerosene was used to facilitate the combustion process. The air inlet holes provided air for the combustion. It took around 1 hour to complete the burning process and 2 hours to completely convert the sample of biomass to biochar. Then, it was collected and the mass was measured to determine its yield. Later, it was analyzed for characterization which is discussed following.

\subsection{Characterization of biochar}

\subsubsection{Proximate analysis}

Proximate analysis was carried out using muffle furnace (Nabertherm, Germany), ranging temperature of $30-3000^{\circ} \mathrm{C}$. Volatile matter and ash contents were measured in accordance with standard ASTM methods (ASTM E872 and ASTM E1755, respectively). Biochar samples of around $1 \mathrm{~g}$ were heated in porcelain crucibles and the weight differences of the samples before and after heating were determined. Moisture content was measured using a moisture analyzer (Model MA 110.R, RADWAG Wagi Elektroniczne, Poland). The fixed carbon content was determined by difference.

\subsubsection{Higher heating value}

The HHV of biochar was measured in an oxygen bomb calorimeter (Parr Instrument Company, Moline, Illinois, USA) according to the ASTM D2015. Approximately, $1 \mathrm{~g}$ of sample was weighed for analysis and the calorimeter was charged with oxygen having a consistent pressure between 20 and $25 \mathrm{~atm}$.

\subsection{Heat loss estimation}

Convection and radiation heat transfer contributed significantly to the heat loss from the pyrolyzer. Heat loss was estimated assuming natural/mixed boundary condition (fire temperature is not equal to the gas temperature). The major pathways of heat loss which is shown in Fig. 2 were-

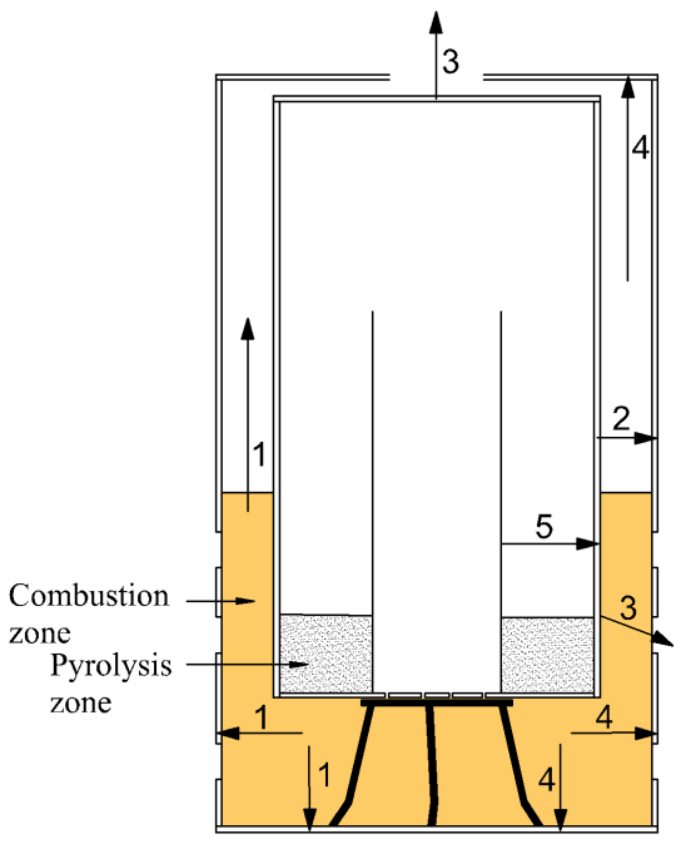

Fig. 2: Flow paths of lost heat

1- From the fire to the outer cylinder surface by both radiation and convection

2- From the inner cylinder surface to the outer cylinder surface by radiation

3- Convection from inner cylinder surface to pores/ambient

4- Convection through gas to outer cylinder surface after fire extinguished

5- Radiation from vertical duct to inner cylinder surface

Convection and radiation heat loss was calculated using the following equations.

$Q_{\text {conv }}=h A\left(T_{\text {in }}-T_{\text {out }}\right)$

$Q_{\text {rad }}=\varepsilon \sigma A\left(T_{\text {in }}{ }^{4}-T_{\text {out }}{ }^{4}\right)$

Heat transfer coefficient was calculated by Nusselt number using the following empirical correlation for free convection.

$N u=C(G r P r)^{m}$

Where, the values of the constants $\mathrm{C}$ and $\mathrm{m}$ were estimated from $\mathrm{Gr}$ and Pr. The physical properties used in the calculation were collected from relevant study [25] and correlation chart [26].

\section{Results and discussion}

\subsection{Yield of biochar}

The mass loss or yield of char is an indication 
Table 1

Yield data of biochar samples produced from biomass feedstock

\begin{tabular}{llll}
\hline Sample type & Feed $(\mathrm{g})$ & Mass of Char $(\mathrm{g})$ & Char yield (mass \%) \\
\hline Wood chips & 675 & 145.00 & 22.00 \\
Rice husk (Granular) & 1000 & 357.50 & 35.75 \\
Rice husk (powdered) & 1000 & 325.00 & 32.50 \\
\hline
\end{tabular}

Table 2

Proximate Analysis data of biochar samples produced from biomass feedstock

\begin{tabular}{lllll}
\hline Sample type & $\begin{array}{l}\text { Volatile } \\
(\text { wt.\%) }\end{array}$ & $\begin{array}{l}\text { Moisture } \\
(\text { wt.\%) }\end{array}$ & $\begin{array}{l}\text { Fixed carbon } \\
(\text { wt.\%) }\end{array}$ & Ash (wt.\%) \\
\hline Wood chips & 25.47 & 6.99 & 63.78 & 3.76 \\
$\begin{array}{l}\text { Rice husk } \\
\text { (Granular) }\end{array}$ & 19.69 & 7.45 & 29.79 & 43.07 \\
$\begin{array}{l}\text { Rice husk } \\
\text { (powdered) }\end{array}$ & 15.88 & 6.89 & 75.09 & 2.13 \\
\hline
\end{tabular}

of the decomposition and volatilization of material in a sample [27]. The yields of pyrolysis product (solid char) from the slow pyrolysis of rice husk and wood chips are shown in Table 1 . It could be seen that the yield for wood chips is $22 \%$ and the yield for rice husk is between $30 \%$ and $40 \%$, which is in agreement with literature findings [21, 23]. It was observed that char yield from rice husk is higher than that of wood chips. This might be due to the fact that there is higher ash content and low volatile matter content in rice husk than in wood chips [28].

\subsection{Proximate analysis and heating value}

Table 2 shows the results of proximate analysis for biochar samples of wood chips and rice husk. It was found from literature that volatile matter content of feedstock of wood chips and granular rice husk were $77.3 \%$ and $56 \%$ respectively $[29,28]$. The volatile matter content of powdered rice husk would be slightly different because it was obtained from boiled paddy. It can be seen from Table 2 that volatile contents for all the char samples varied between $15 \%$ and $26 \%$ meaning most of the volatiles were released during devolatilization. The proximate analysis of the char produced showed good agreement with the literature. Lower moisture content and lower ash content of biochar from wood chips and powdered rice husk lead to greater value of fixed carbon indicating good quality of those char samples.

The ash content of granular rice husk char is $43.07 \%$, which is high indicating that it might be good for soil replenishment by increasing nutrient retention in soil [30]. A possible reason of ash content being significantly lower for powdered rice husk than for granular rice husk is that the powdered one was obtained from boiled paddy and most of the inorganics might have been leached away. This is also evident in the measured heating values which is shown in Table 3. The HHV of char from wood chips is greater than that of granular rice husk. Also, it can be observed that the HHV of char is more than that of raw biomass as expected.

Table 3

HHV data of raw biomass and char

\begin{tabular}{lll}
\hline Sample type & $\begin{array}{l}\mathrm{HHV} \text { of } \\
\text { raw } \\
\text { biomass } \\
\left(\mathrm{MJkg}^{-1}\right)\end{array}$ & $\begin{array}{l}\mathrm{HHV} \text { of } \\
\text { char } \\
\left(\mathrm{MJkg}^{-1}\right)\end{array}$ \\
\hline $\begin{array}{l}\text { Wood chips } \\
\begin{array}{l}\text { Rice husk } \\
\text { (Granular) }\end{array}\end{array}$ & 18.46 & 27.55 \\
\hline
\end{tabular}

\subsection{Heat loss and cost analysis of the pyrolyzer}

Heat loss from the pyrolyzer during the pyrolysis process was estimated to assess the energy consumption efficiency of the pyrolyzer. Heat energy was supplied to it mainly by combustion of biomass. Since the combustion zone of the pyrolyzer was partially open to the atmosphere, it was subjected to significant amount of heat loss. Various losses were estimated by utilizing Eq. (1) to Eq. (3). Heat input to the pyrolyzer was estimated using the heat of combustion of wood and kerosene. The total heat loss was found to be $76.54 \%$, which is high as anticipated. The pyrolyzer provided enough heat for biomass conversion although it lost heat significantly.

The proposed pyrolyzer is portable and the probable users (i.e., farmers) would be able to use it without any additional cost or equipment for amending the soil. The biochar produced from this pyrolyzer can be a substitute for soil amendment. Table 4 shows the item-wise costing of the pyrolyzer. The fixed cost of the pyrolyzer was approximately 1650 BDT (19.55 USD). To produce $1 \mathrm{~kg}$ of biochar, 
the operating cost was found to be around 30 BDT (0.36 USD), which includes only the cost of kerosene. This means, the pyrolyzer is cheap and affordable. It provides an effective mean to the farmers to improve the soil quality, making it nutrient rich and suitable for production.

Table 4

Item-wise costing of the pyrolyzer

\begin{tabular}{ll}
\hline Item & Cost (BDT(USD)) \\
\hline Outer cylinder & $800(9.60)$ \\
Inner cylinder & $600(7.20)$ \\
Lifting support & $250(3.00)$ \\
\hline Total cost & $1650(19.55)$ \\
\hline
\end{tabular}

\section{Conclusion}

There is a general issue with mass production of biochar at the consumer end at a low cost. Creating an inert environment is often not straightforward. In the current work, a modular pyrolyzer was introduced which can create the inert environment required for biomass conversion at a very low cost which is feasible for modular scale implementation. Also, the produced biochar showed similar qualities as the biochar prepared from conventional and expensive methods for water holding and soil enrichment properties.

Further research is being carried out to study all the properties of the biochar made and to improve the modular pyrolyzer design for better yield and energy efficiency.

\section{Acknowledgement}

The authors like to sincerely thank Ms. Ummay Salma and Mr. Assame Arnob for supporting the analytical work carried out in the laboratory.

\section{Nomenclature}

$\begin{array}{ll}\text { HHV } & \text { Higher heating value } \\ h & \text { Convection heat transfer coefficient } \\ A & \text { Area of heat transfer } \\ T_{\text {in }} & \text { Inlet temperature } \\ T_{\text {out }} & \text { Outlet temperature } \\ Q_{\text {conv }} & \text { Convection heat loss } \\ Q_{\text {rad }} & \text { Radiation heat loss } \\ N u & \text { Nusselt number } \\ G r & \text { Grashof number }\end{array}$

\author{
Pr Prandtl number \\ Greek letters \\ $\varepsilon \quad$ Emissivity of the surface \\ $\sigma \quad$ Stefan-Boltzmann constant
}

\section{References}

[1] Ahmad, M.; Rajapaksha, A. U.; Lim, J. E.; Zhang, M.; Bolan, N.; Mohan, D.; Vithanage, M.; Lee, S. S.; Ok, Y. S. Biochar as a Sorbent for Contaminant Management in Soil and Water: A Review. Chemosphere 2014, 99, 19-33. https://doi.org/10.1016/j.chemosphere.2013.10.071.

[2] Atkinson, C. J.; Fitzgerald, J. D.; Hipps, N. A. Potential Mechanisms for Achieving Agricultural Benefits from Biochar Application to Temperate Soils: A Review. Plant Soil 2010, 337 (1), 1-18. https://doi.org/10.1007/s11104-010-0464-5.

[3] Smith, P. Soil Carbon Sequestration and Biochar as Negative Emission Technologies. Glob. Chang. Biol.2016, $22 \quad$ (3), 1315-1324. https://doi.org/10.1111/gcb.13178.

[4] Demirbas, M. F.; Balat, M. Biomass Pyrolysis for Liquid Fuels and Chemicals: A Review. J. Sci. Ind. Res. (India). 2007, 66 (10), 797-804.

[5] Anthony V. Bridgwater. Review Paper; Biomass Fast Pyrolysis. Bioresour. Technol. 2004, 85 (2), 21-49. https://doi.org/10.1016/j.biortech.2010.12.075.

[6] Zhang, M.; Ok, Y. S. Biochar Soil Amendment for Sustainable Agriculture with Carbon and Contaminant Sequestration. Carbon Manag. 2014, 5 (3),

255-257. https://doi.org/10.1080/17583004.2014.973684.

[7] Chan, K. Y.; Van Zwieten, L.; Meszaros, I.; Downie, A.; Joseph, S. Agronomic Values of Greenwaste Biochar as a Soil Amendment. Aust. J. Soil Res. 2007, $\quad 45 \quad$ (8), 629-634. https://doi.org/10.1071/SR07109.

[8] Sohi, S. P. Carbon Storage with Benefits. Science (80-. ). 2012, $338 \quad$ (6110), 1034-1035. https://doi.org/10.1126/science.1225987.

[9] Novak, J.; Ro, K.; Ok, Y. S.; Sigua, G.; Spokas, K.; Uchimiya, S.; Bolan, N. Biochars Multifunctional Role as a Novel Technology in the Agricultural, Environmental, and Industrial Sectors. Chemosphere 2016, 142, 1-3. https://doi.org/10.1016/j.chemosphere.2015.06.066.

[10] Gaunt, J. L.; Lehmann, J. Energy Balance and Emissions Associated with Biochar Sequestration and Pyrolysis Bioenergy Production. Environ. Sci. Technol. 2008, 42 (11), 4152-4158. https://doi.org/10.1021/es071361i.

[11] Ennis, C. J.; Evans, A. G.; Islam, M.; RalebitsoSenior, T. K.; Senior, E. Biochar: Carbon Sequestration, Land Remediation, and Impacts on Soil Microbiology. Crit. Rev. Environ. Sci. Technol. 2012, $42 \quad$ (22), 2311-2364. https://doi.org/10.1080/10643389.2011.574115. 
[12] Spokas, K. A.; Reicosky, D. C. <Spokas 2009 GHG Emissions.Pdf >. Impacts Sixt. Differ. Biochars Soil Greenh. Gas Prod. 2009, 3 (612), 179-193.

[13] Zhang, M.; Cheng, G.; Feng, H.; Sun, B.; Zhao, Y.; Chen, H.; Chen, J.; Dyck, M.; Wang, X.; Zhang, J.; Zhang, A. Effects of Straw and Biochar Amendments on Aggregate Stability, Soil Organic Carbon, and Enzyme Activities in the Loess Plateau, China. Environ. Sci. Pollut. Res. 2017, 24 (11), 1010810120. https://doi.org/10.1007/s11356-017-8505-8.

[14] Thomazini, A.; Spokas, K.; Hall, K.; Ippolito, J.; Lentz, R.; Novak, J. GHG Impacts of Biochar: Predictability for the Same Biochar. Agric. Ecosyst. Environ. 2015, 207, 183-191. https://doi.org/10.1016/j.agee.2015.04.012.

[15] Novak, J.; Lima, I.; Xing, B.; Gaskin, J.; Steiner, C.; Das, K.; Ahmedna, M.; Rehrah, D.; Watts, D.; Busscher, W. Characterization of Designer Biochar Produced at Different Temperatures and Their Effects on a Loamy Sand. Ann. Environ. Sci. 2009, 3 (1), 195-206.

[16] Mohan, D.; Sarswat, A.; Ok, Y. S.; Pittman, C. U. Organic and Inorganic Contaminants Removal from Water with Biochar, a Renewable, Low Cost and Sustainable Adsorbent - A Critical Review. Bioresour. Technol. 2014, 160, 191-202. https://doi.org/10.1016/j.biortech.2014.01.120.

[17] Yao, Y.; Gao, B.; Zhang, M.; Inyang, M.; Zimmerman, A. R. Effect of Biochar Amendment on Sorption and Leaching of Nitrate, Ammonium, and Phosphate in a Sandy Soil. Chemosphere 2012, 89 (11), $1467-1471$ https://doi.org/10.1016/j.chemosphere.2012.06.002.

[18] Sapek, A. Magnitude of Nitrogen and Phosphorus Delivered to Baltic Sea via Polish Rivers. Polish J. Environ. Stud. 2014, 23 (6), 2191-2198.

[19] Zheng, S.; Xiao, M.; Miao, Z. Nitrogen Losses in Paddy Field Drainage Modified by Different Water Level Regulations. Polish J. Environ. Stud. 2017, 26 (3), $1393-1401$ https://doi.org/10.15244/pjoes/67337.

[20] Maienza, A.; Genesio, L.; Acciai, M.; Miglietta, F.; Pusceddu, E.; Vaccari, F. P. Impact of Biochar Formulation on the Release of Particulate Matter and on Short-Term Agronomic Performance. Sustain. 2017, 90 (7), $1-10$. https://doi.org/10.3390/su9071131.

[21] Hsu, C. P.; Huang, A. N.; Kuo, H. P. Analysis of the Rice Husk Pyrolysis Products from a Fluidized Bed Reactor. Procedia Eng. 2015, 102, 1183-1186. https://doi.org/10.1016/j.proeng.2015.01.244.
[22] Vieira, F. R. A Study of Biochar Yield from the Slow Pyrolysis of Rice Husk. 2018, No. April 2020. https://doi.org/10.26678/abcm.cobem2017.cob172258.

[23] Veksha, A.; McLaughlin, H.; Layzell, D. B.; Hill, J. M. Pyrolysis of Wood to Biochar: Increasing Yield While Maintaining Microporosity. Bioresour. Technol. 2014, 153, 173-179. https://doi.org/10.1016/j.biortech.2013.11.082.

[24] Ronsse, F.; van Hecke, S.; Dickinson, D.; Prins, W. Production and Characterization of Slow Pyrolysis Biochar: Influence of Feedstock Type and Pyrolysis Conditions. GCB Bioenergy 2013, 5 (2), 104-115. https://doi.org/10.1111/gcbb.12018.

[25] Kirtania, K.; Bhattacharya, S. Coupling of a Distributed Activation Energy Model with Particle Simulation for Entrained Flow Pyrolysis of Biomass. Fuel Process. Technol. 2015, 137, 131-138. https://doi.org/10.1016/j.fuproc.2015.04.014.

[26] Carr, N. L.; Kobayashi, R.; Burrows, D. B. Viscosity of Hydrocarbon Gases Under Pressure. J. Pet. Technol. 1954, $6 \quad$ (10), 47-55. https://doi.org/10.2118/297-g.

[27] Rutherford, D. W.; Wershaw, R. L.; Rostad, C. E.; Kelly, C. N. Effect of Formation Conditions on Biochars: Compositional and Structural Properties of Cellulose, Lignin, and Pine Biochars. Biomass and Bioenergy 2012, 46, 693-701. https://doi.org/10.1016/j.biombioe.2012.06.026.

[28] Yu, Y.; Yang, Y.; Cheng, Z.; Blanco, P. H.; Liu, R.; Bridgwater, A. V.; Cai, J. Pyrolysis of Rice Husk and Corn Stalk in Auger Reactor. 1. Characterization of Char and Gas at Various Temperatures. Energy and Fuels 2016, $30 \quad$ (12), 10568-10574. https://doi.org/10.1021/acs.energyfuels.6b02276.

[29] Sinha, S.; Jhalani, A.; Ravi, M.; Ray Chaudhury, A. Modelling of Pyrolysis in Wood: A Review. SESI J. 2000, 10 (1), 41-62.

[30] Domingues, R. R.; Trugilho, P. F.; Silva, C. A.; De Melo, I. C. N. A.; Melo, L. C. A.; Magriotis, Z. M.; Sánchez-Monedero, M. A. Properties of Biochar Derived from Wood and High-Nutrient Biomasses with the Aim of Agronomic and Environmental Benefits. PLoS One 2017, 12 (5), 1-19. https://doi.org/10.1371/journal.pone.0176884.

CB Bangladesh Uni. of Engg. \& Tech. 